\title{
INVESTIGATION OF THE EFFICIENCY OF USING HOP LEAVENS IN THE TECHNOLOGY OF WHEAT BREAD
}

\author{
Valentina Rak \\ Department of Technology of bakery and confectionery products \\ National University of food technologies \\ 68 Volodymyrska str., Kyiv, Ukraine, 01601 \\ valentina.rak1954@gmail.com \\ Vira Yurchak \\ Department of Technology of bakery and confectionery products \\ National University of food technologies \\ 68 Volodymyrska str., Kyiv, Ukraine, 01601 \\ yrchakvg@ukr.net \\ Olena Bilyk \\ Department of Technology of bakery and confectionery products \\ National University of food technologies \\ 68 Volodymyrska str., Kyiv, Ukraine, 01601 \\ bilyklena@gmail.com \\ Volodymyr Bondar \\ Department of Thermal Power and Refrigeration Engineering \\ National University of food technologies \\ 68 Volodymyrska str., Kyiv, Ukraine, 01601 \\ ivanovish976@gmail.com
}

\begin{abstract}
The use brews in preparing leavens provides yeast cells' and lactbacteria's life activity with nutrients. The process of sugaring of bitter brews depending on parameters of their preparation was studied, and it was established, that the most intensity of sugars accumulation takes place during 1 hour of sugaring at the moisture mass share in brew $78,0 \%$. It is recommended to use such devele oped bitter brew in the technology of rye-wheat bread with the small content of rye four $(10 \ldots 12 \%)$ or wheat bread of sorted flour.

It is recommended to use the four-phase method of preparing dough by the scheme: "sugared "bitter" brew $\rightarrow$ brew, fere mented by homo-enzymatic thermophilic FMB L. Delbrükii-76 $\rightarrow$ hop leaven, fermented by yeast of S. cerevisiae L-1 race and homo-enzymatic mesophilic LMB L. Plantarum-30 $\rightarrow$ dough». At using $25 \%$ of leaven, the acidity of dough and ready products decreases by 2,0 degrees. That is why it is recommended to use this method of preparing bakery products of wheat flour. At that there is provided the better fluffiness and crumb state and prolongation of freshness of bakery products. According to the research results, there was developed the apparatus-technological productive scheme that can be introduced on special lines.
\end{abstract}

Keywords: bitter brews, hop leavens, ferment, lactate bacteria, bread, staling.

\section{Introduction}

The essence of the technology of bread on hop leavens is in fact that microflora of leavens develops on the flour nutrient medium that is "bitter" brew, prepared of flour and hop broth [1].

According to different variants of the technology, brews fermentation was realized spontaneously in solution cycles [2] or using pure cultures of yeast and lactobacteria [1]. Bitter brew is ofe ten used in the solution cycle, then so-called sweet brew that doesn't contain hop broth is prepared in the production cycle [3]. The defect of such leavens is rather fast development of side microflora, in which result, their acidity essentially grows. So, they were used for preparing rye-wheat bread or wheat one of the wholegrain and second sort. 
Today bakery enterprises try to adapt existent technologies of bread on hop leavens to modern conditions. The most producer of rye-wheat bread "On hop" using hop leavens is for today SE OSC "Kyivbread" "Breadenterprise No. 12" that produces this bread for more than ten years in essential amounts [4]. As it was demonstrated by studies, bread is insufficiently fluffy, gets stale fast and loses consumption properties [5]. From our point of view, one of causes is a small amount of flour, fermented in leavens- $12,0 \%$ of flour mass in dough, short period of dough fermentation, insufficient amount of brewed flour $-6,0 \%$ and so on.

For today there was not realized the estimation of different ways of preparing dough on hop leavens. Optimal conditions for preparing brews remain unexplained: moisture, sugaring duration. It is necessary to chose strains of microorganisms, technological parameters of brew, leaven, dough preparation that would provide producing bread of the high quality.

The aim of the study was to investigate the influence of parameters of bitter brews preparation on the dynamics of sugars accumulation and quality parameters of hop leavens, prepared using them, and also the influence of parameters of preparation of leavens themselves and their quality.

The following tasks must be solved for attaining the set aim:

- to study rheological properties of semi-products;

- to realize the comparative study of different methods of preparing dough on hop leavens;

- to study their influence on the bread quality.

\section{Materials and Methods}

For determining the influence of the ratio of rye peeled flour and hop broth in brew 1:2, 1:3 and $1: 4$ on leavens' quality parameter, brew was prepared with the moisture mass share $72,0 \%$, $78,0 \%$ and $82,0 \%$, and leaven $78,0 \%$. The total amount of flour in it was $12,0 \%$ of the flour mass in dough. Sugars accumulation in brews and leavens, prepared on developed brews during four hours of fermentation was determined by the iodometric method [6].

The work studied the influence of a temperature and moisture mass share on the acidity and lifting force of leavens. There was studied the influence of the temperature change of hop leavens within $25 \ldots 26^{\circ} \mathrm{C}$ and $28 \ldots 29^{\circ} \mathrm{C}$ and moisture mass share of brews $72,0 \%, 78,0 \%$ and $82,0 \%$ on quality parameters of hop leavens [7].

This work determines rheological characteristics of bitter brews at the ratio of flour and hop broth 1:2 and 1:3, and also rheological characteristics of hop leavens, nourished by these brews. There were studied rheological properties of brew immediately after brewing and after 1 hour of sugaring. Leavens were nourished by sugared brews, at that brew was introduced together with $6,0 \%$ and $12,0 \%$ of brewed flour. In total leavens contained $12,0 \%$ of flour from its mass in dough. Moisture of hop leavens was 78,0\%. Rheological characteristics of leavens were determined imi mediately after nourishing and after fermentation. The fermentation duration was 3 hours.

The determination of rheological characteristics of brews and leavens was realized on a device "Rheotest-2" (made by "RheoTest Messgerate Medingen GmbH", Germany). According to measuring data, viscosity curves were constructed depending on the shift tension, and current curves (dependence of the deformation speed on tension).

The following structural-mechanical parameters were determined, according to obtained graphs:

- dynamic viscosity of the non-destructed structure $\left(\eta_{0}, P a \cdot s\right)$,

- dynamic viscosity of the destructed structure $\left(\eta_{m}, P a \cdot s\right)$,

- value of anomaly in viscosity $\left(\eta_{0}-\eta_{\mathrm{m}}, \mathrm{Pa} \cdot \mathrm{s}\right)$,

- character of the created scheme, $\left(\mathrm{P}_{\mathrm{k} 1}, \mathrm{~Pa}\right)$,

- dynamic limit of the system's ability to fluidity $\left(\mathrm{P}_{\mathrm{k} 2}, \mathrm{~Pa}\right)$,

- firmness of the created structural framework $\left(\mathrm{P}_{\mathrm{m}}, \mathrm{Pa}\right)$,

- firmness of structural connections $\left(\mathrm{P}_{\mathrm{k} 1} / \mathrm{P}_{\mathrm{k} 2}, \mathrm{~Pa}\right)$,

- tension diapason $\left(\mathrm{P}_{\mathrm{m}} / \mathrm{P}_{\mathrm{K} 1}, \mathrm{~Pa}\right)$.

For studying parameters of the technological process, biochemical, physical-chemical changes in dough and qualitative parameters of bread, laboratory baking was realized. Leaven was introduced in dough in the amount $50,0 \%$ of the flour mass in dough (variant No. 1), in ferment in 
the same quality (variant No. 2), and in ferment in the amount $25,0 \%$ of the flour mass in dough (variant No. 3). In the last case the twofold decrease of leaven dosage is conditioned by the necessity of decreasing the dough acidity. The reason was also that dosage of liquid yeast for preparing wheat sorts of bread is $20 \ldots 25 \%$ of the flour mass in dough $[8,9]$. Leaven with the mass $50,0 \mathrm{~kg}$ contained $12,0 \%$ of rye peeled flour, a half of which was introduced with brew in brewed state. Leavens were fermented for 3,5 hours, their acidity was 7,8 degrees, lifting force $-17 \mathrm{~min}$. Ferment contained $60,0 \%$ of flour (large dense ferments), their fermentation duration was 3 hours. Ferment and dough were prepared without adding pressed yeast. The moisture mass share in dough $44,0 \%$, fermentation duration $-30 \mathrm{~min}$.

The quality of semi-products was estimated by acidity, lifting force and accumulation of fixed acids. Extraction of organic acids from the studied objects is grounded on their different solubility in water, alcohol and ether [6].

The bread quality was estimated by physical-chemical (specific volume, acidity) and organoleptic parameters (look, crust surface state, porosity structure, taste, smell). The duration of keeping freshness by products was studied by the change of structural-mechanical properties of crumb. Its total deformation was determined after 72 hours of storage on a penetrometer AP 4/1 ("Finemass", Germany). The complex quality parameter was estimated by the point scale of bakery products quality, including the most essential quality parameters - specific volume, form correctness, crust color, crumb deformation after 72 hours of storage, crumbling, form stability, crust surface state, crumb color, porosity structure, smell, taste, chewing properties [7].

The degree of staling of products was studied also by crumbling. The staler bread, the less swallowed crumb is. Crumbling was estimated by crumbs formation as a result of rubbing two pieces of bread with the mass $5 \mathrm{~g}$, cut as parallelepiped as a result of shaking during 5 min on a vibration shaker IKA HS 501 digital (IKA ${ }^{\circledR}$-Werke GmbH \& Co. KG (Germany)). Crumbling was expressed as a ratio of a crumb mass to a bread batch mass in percents [7].

The content of aromatic substances in ready bread products of siftings was estimated by the number of bisulphite-binding compounds [10]. This method is grounded on the ability to bound aldehydes and certain ketones by sodium bisulphite, creating adducts. This method is in the preliminary removal of non-reacted bisulphite by iodine with further destruction of adducts by sodium bicarbonate and titration of released bisulphate, equivalent to the content of carbonyl compounds.

The results of the experimental studied were processed using methods of the calculation of statistical reliability of measuring results. Approximations of the empirical data were realized using e-tables MSExcel (version 2010).

\section{Results}

The analysis of sugars accumulation in bitter brews demonstrated the growth of the amount of sugars during four hours of sugaring. But the most increment of the sugars amount was observed during the first hour of sugaring, near $100 \%$. The moisture mass share increase up to 78,0 \% also positively influences sugars accumulation.

The use of bitter brews, prepared by the ratio of flour and hop broth $1: 3 \div 1: 4$, favors the int crease of the initial content of sugars in hop leavens by $2,2 \ldots 1,8 \%$ of a mass of dry substances (DS) comparing with leavens on denser brews (flour and hop broth 1:2).

The initial amount of sugars in hop leavens, prepared using bitter brews after 2 hours of sugaring is $12,6 \%$ of DS at the ratio of flour and hop broth in brews $1: 2$ and $15,3 \ldots 15,5 \%$ of DS at the ratio of flour and hop broth 1:3 and 1:4. Thus, at using more liquid brews the content of sugars in leaven grows approximately by $25,0 \%$ comparing with leavens with denser brews.

It is more effective to brew $12,0 \%$ of flour. In this case the content of sugars in leaven grows in $1,5 \ldots 2,0$ times and is $15,8 \ldots 20,7 \%$ of SD and $21,0 \ldots 24,6 \%$ of SD if to use brews, sugared during 1 and 2 hours, respectively.

The increase of the sugars content in hop leavens slightly influences the process of acids accumulation and intensifies its only at the beginning of fermentation. It testifies that the sugars' content in leavens $13,2 \ldots 15,8 \%$ of DS is enough for nourishing latcobacteria in leavens and essen $€$ 
tially improves their lifting force. At the sugars' content $12,8 \ldots 13,2 \%$ of SD of leaven they have the lifting force $20 \ldots 18 \mathrm{~min}$ in $3 . .4$ hours of fermentation, at the sugars content $15,5 \ldots 20,8 \%$ of SD such lifting force is achieved already after 2 hours after fermentation of leavens.

The study of the influence of the moisture mass share in leavens on their quality parameters demonstrated (Table 1) that the acidity of leavens that contain $6,0 \%$ of flour in the brewed state grows more intensively at less moisture, especially, the most acidity is inherent to leaven with the moisture mass share $72,0 \%$. The lifting force of leavens with the moisture mass share increase ims proves that is explained by the better fermentation activity of yeast cells in the more liquid medium. At the moisture mass share in leaven $78,0 \ldots 82,0 \%$ the best lifting force $18 \ldots 19 \mathrm{~min}$ is achieved in 3 hours of fermentation.

Table 1

Influence of moisture mass share on the quality of hop leaven $n=3, p \leq 0,95$

\begin{tabular}{|c|c|c|c|c|c|}
\hline \multirow{4}{*}{ Parameters } & \multicolumn{5}{|c|}{ Leavens with flour in the brewed state, $\%$} \\
\hline & \multicolumn{3}{|c|}{6,0} & \multicolumn{2}{|c|}{12,0} \\
\hline & \multicolumn{5}{|c|}{ Values for leaven with the moisture mass share, $\%$} \\
\hline & 72,0 & 78,0 & 82,0 & $\mathbf{7 8 , 0}$ & 82,0 \\
\hline \multicolumn{6}{|l|}{ Acidity, degrees } \\
\hline initial & 6,5 & 6,3 & 6,3 & 6,4 & 6,4 \\
\hline in 1 hour & 8,4 & 7,8 & 7,6 & 8,0 & 7,8 \\
\hline 2 hours & 9,2 & 8,4 & 7,9 & 8,8 & 8,0 \\
\hline 3 hours & 9,8 & 9,2 & 8,8 & 9,4 & 9,0 \\
\hline 4 hours & 10,6 & 10,0 & 9,6 & 10,0 & 9,8 \\
\hline \multicolumn{6}{|c|}{ Lifting force, $\min$} \\
\hline initial & 28 & 25 & 24 & 23 & 22 \\
\hline in 1 hour & 24 & 23 & 22 & 21 & 20 \\
\hline 2 hours & 22 & 21 & 20 & 20 & 18 \\
\hline 3 hours & 21 & 19 & 18 & 18 & 17 \\
\hline 4 hours & 20 & 17 & 17 & 17 & 15 \\
\hline
\end{tabular}

The analogous experiments were realized for leavens, contained $12,0 \%$ of flour in the brewed state. Leaven with the moisture mass share $72,0 \%$ was not prepared in these experiments, because it is too dense for pumping over.

The Table 2 demonstrates that the dynamic viscosity of the non-destructed structure of bitter brews at the ratio of flour and hop broth 1:2 is 46,1 $\mathrm{Pa} \cdot \mathrm{s}$ and is higher than for brews at the ratio of flour and hop broth 1:3, in 6,5 times (7,7 Pa.s). After 1 hours of sugaring the viscosity decreases in both brews and is respectively 15,4 and 5,1 Pas, that is higher for brew at the ratio of flour and hop broth 1:2 in 3 times. 
Table 2

Rheological characteristics of bitter brews $n=3, p \leq 0,95$

\begin{tabular}{|c|c|c|c|c|c|c|c|c|}
\hline $\begin{array}{c}\text { Semi- } \\
\text { product }\end{array}$ & $\begin{array}{c}\text { Dynamic } \\
\text { viscosity of the } \\
\text { non-destruct- } \\
\text { ed structure } \\
\eta_{0}, \text { Pas }\end{array}$ & $\begin{array}{c}\text { Dynamic } \\
\text { viscosity of } \\
\text { the destructed } \\
\text { structure, } \eta_{\mathrm{m}} \text {, } \\
\text { Pas }\end{array}$ & $\begin{array}{c}\text { Viscosity } \\
\text { anomaly } \eta_{0} \\
-\eta_{m}, \operatorname{Pa} \cdot \mathbf{s}\end{array}$ & $\begin{array}{c}\text { Character } \\
\text { of system } \\
\text { formation } \\
P_{k 1}, \mathrm{~Pa}\end{array}$ & $\begin{array}{c}\text { Dynamic } \\
\text { limit of } \\
\text { the system } \\
\text { ability to } \\
\text { fluidity, } \\
\mathrm{P}_{\mathrm{k} 2}, \mathrm{~Pa}\end{array}$ & $\begin{array}{c}\text { Firmness } \\
\text { of the } \\
\text { structural } \\
\text { framework, } \\
\mathrm{P}_{\mathrm{m}}, \mathrm{Pa}\end{array}$ & $\begin{array}{c}\text { Firmness of } \\
\text { structural } \\
\text { connections, } \\
\mathbf{P}_{\mathrm{k} 1} / \mathbf{P}_{\mathrm{k} 2}, \mathbf{P a}\end{array}$ & $\begin{array}{c}\text { Tension } \\
\text { diapa- } \\
\text { son, } \\
\mathbf{P}_{\mathbf{m}} / \mathbf{P}_{\mathrm{k} 1}, \\
\mathbf{P a}\end{array}$ \\
\hline $\begin{array}{c}\text { Brew after } \\
\text { brewing at } \\
\text { the ratio of } \\
\text { flour and } \\
\text { hop broth } \\
1: 2\end{array}$ & 46,1 & 17,7 & 28,4 & 150,0 & 670 & 1190 & 0,2 & 7,9 \\
\hline $\begin{array}{c}\text { Sugared } \\
\text { brew after } \\
\text { brewing at } \\
\text { the ratio of } \\
\text { flour and } \\
\text { hop broth } \\
1: 2\end{array}$ & 15,4 & 6,0 & 9,4 & 110,0 & 1025 & 1320 & 0,1 & 12,0 \\
\hline $\begin{array}{c}\text { Brew after } \\
\text { brewing at } \\
\text { the ratio of } \\
\text { flour and } \\
\text { hop broth } \\
1: 3\end{array}$ & 7,7 & 3,2 & 4,5 & 20,0 & 300 & 875 & 0,1 & 43,7 \\
\hline $\begin{array}{c}\text { Sugared } \\
\text { brew after } \\
\text { brewing at } \\
\text { the ratio of } \\
\text { flour and } \\
\text { hop broth } \\
1: 3\end{array}$ & 5,1 & 1,1 & 4,1 & 0 & 20 & 27 & 0 & 0 \\
\hline
\end{tabular}

The analogous dependencies are observed for the index of dynamic viscosity of the destructed structure. The viscosity anomaly that characterizes the firmness of the permolecular structure, formed in the system, demonstrate that brew at the ratio of flour and hop broth 1:2 has the most firm structure, and one at the ratio of flour and hop broth 1:3 is characterized by weakening of the structure. After sugaring the firmness of the structure decreases, but in brews at the ratio of flour and hop broth1:2 it is 2 times higher comparing with ones at the ratio of flour and hop broth 1:3.

The dynamic limit of the system ability to fluidity in sugared brew at the ratio of flour and hop broth 1:2 is the highest $-1025 \mathrm{~Pa}$, and in sugared brew at the ratio of flour and hop broth 1:3 its essential decrease is observed and it is $20 \mathrm{~Pa}$.

Sugared brew, prepared at the ratio of flour and hop broth 1:2 is also a structured body, and only brew, prepared at the ratio of flour and hop broth 1:3 gets properties of a liquid-like structured body after 1 hour of sugaring. The firmness of the created structural framework grows at brew sugaring at the ratio of flour and hop broth 1:2 and essentially decreases at the ratio of flour and hop broth 1:3.

As it is testified by the obtained data (Table 3) introduction of 12,0\% of brewed flour in hop leaven results in the growth of the dynamic viscosity of its non-destructed structure comparing with leavens that contain $6,0 \%$ of brewed flour at any ratio of flour and hop broth that is rather logic. The analogous dependencies are observed for the dynamic viscosity of destructed structure. 
Table 3

Rheological characteristics of hop leavens $n=3, p \leq 0,95$

\begin{tabular}{|c|c|c|c|c|c|c|c|c|}
\hline Semi-product & $\begin{array}{c}\text { Dynamic vis- } \\
\text { cosity of the } \\
\text { non-destruct- } \\
\text { ed structure } \\
\eta_{0} \text {, Pas }\end{array}$ & $\begin{array}{c}\text { Dynamic } \\
\text { viscosi- } \\
\text { ty of the } \\
\text { destructed } \\
\text { structure, } \\
\eta_{m}, \text { Pa:s }\end{array}$ & $\begin{array}{c}\text { Viscosity } \\
\text { anomaly } \\
\eta_{0}-\eta_{\mathrm{m}} \\
\text { Pa's }\end{array}$ & $\begin{array}{l}\text { Char- } \\
\text { acter of } \\
\text { system } \\
\text { forma- } \\
\text { tion } P_{k 1} \text {, } \\
P \text { a }\end{array}$ & $\begin{array}{c}\text { Dynamic } \\
\text { limit of } \\
\text { the system } \\
\text { ability to } \\
\text { fluidity, } P_{\mathrm{k} 2} \text {, } \\
\text { Pa }\end{array}$ & $\begin{array}{l}\text { Firmness } \\
\text { of the } \\
\text { structural } \\
\text { frame- } \\
\text { work, } P_{\mathrm{m}} \text {, } \\
\quad \mathrm{Pa}\end{array}$ & $\begin{array}{c}\text { Firm- } \\
\text { ness of } \\
\text { structural } \\
\text { connec- } \\
\text { tions, } \\
\mathbf{P}_{\mathrm{k} 1} / \mathbf{P}_{\mathrm{k} 2}, \mathrm{~Pa}\end{array}$ & $\begin{array}{c}\text { Tension } \\
\text { diapason, } \\
\mathbf{P}_{\mathbf{m}} / \mathbf{P}_{\mathrm{k} 1}, \\
\mathbf{P a}^{-}\end{array}$ \\
\hline \multicolumn{9}{|c|}{ Brews after nourishing } \\
\hline $\begin{array}{l}\text { Leaven that contains } \\
12,0 \% \text { of brewed } \\
\text { flour at the ratio of } \\
\text { flour and hop broth in } \\
\text { brew } 1: 2\end{array}$ & 3,2 & 0,6 & 2,7 & 21,0 & 190 & 335 & 0,1 & 16,0 \\
\hline $\begin{array}{l}\text { Leaven that contains } \\
6,0 \% \text { of brewed flour } \\
\text { at the ratio of flour } \\
\text { and hop broth in } \\
\text { brew } 1: 2\end{array}$ & 1,4 & 0,1 & 1,3 & 10,0 & 60 & 90 & 0,2 & 9,0 \\
\hline $\begin{array}{l}\text { Leaven that contains } \\
12,0 \% \text { of brewed } \\
\text { flour at the ratio of } \\
\text { flour and hop broth in } \\
\text { brew } 1: 3\end{array}$ & 4,1 & 0,8 & 3,3 & 40,0 & 254 & 460 & 0,2 & 11,5 \\
\hline $\begin{array}{l}\text { Leaven that contains } \\
6,0 \% \text { of brewed flour } \\
\text { at the ratio of flour } \\
\text { and hop broth in } \\
\text { brew } 1: 3\end{array}$ & 2,1 & 0,1 & 2,0 & 20,0 & 100 & 135 & 0,2 & 6,8 \\
\hline
\end{tabular}

\section{Fermented leavens}

\begin{tabular}{|c|c|c|c|c|c|c|c|c|}
\hline $\begin{array}{l}\text { Leaven that contains } \\
12,0 \% \text { of brewed } \\
\text { flour at the ratio of } \\
\text { flour and hop broth in } \\
\text { brew } 1: 2\end{array}$ & 9,2 & 0,4 & 8,8 & 25,0 & 283 & 392 & 0,1 & 15,7 \\
\hline $\begin{array}{l}\text { Leaven that contains } \\
6,0 \% \text { of brewed flour } \\
\text { at the ratio of flour } \\
\text { and hop broth in } \\
\text { brew } 1: 2\end{array}$ & 1,5 & 0,1 & 1,4 & 0 & 110 & 143 & 0 & 0 \\
\hline $\begin{array}{l}\text { Leaven that contains } \\
12,0 \% \text { of brewed } \\
\text { flour at the ratio of } \\
\text { flour and hop broth in } \\
\text { brew } 1: 3\end{array}$ & 12,3 & 0,4 & 11,8 & 100,0 & 335 & 470 & 0,3 & 3,4 \\
\hline $\begin{array}{l}\text { Leaven that contains } \\
6,0 \% \text { of brewed flour } \\
\text { at the ratio of flour } \\
\text { and hop broth in } \\
\text { brew } 1: 3\end{array}$ & 2,3 & 0,2 & 2,1 & 11,5 & 110 & 180 & 0,1 & 9,6 \\
\hline
\end{tabular}

Leavens, prepared using bitter brews at the ratio of flour and hop broth 1:3, had a bit higher dynamic viscosity parameters of both non-destructed and destructed structures comparing with ones, prepared using brews at the ratio of flour and hop broth 1:2. As it is demonstrated above, the dynamic viscosity of brews themselves is higher at the ratio of flour and hop broth 1:2. 
Such contradiction can be easily explained if to take into account that at preparing brews at the ratio of flour and hop broth 1:3 the more amount of water participates in gelatinization of flour starch, than in brews at the ratio of flour and hop broth 1:2, so, is bound osmotically. In the last case the more amount of water, introduced in leaven, doesn't participate in gelatinization of flour starch and is unbound.

Fermented leavens, prepared using brew at the ratio of flour and hop broth 1:2, has the less viscosity than ones with brews at the ratio of flour and hop broth 1:3 like in the case with just nourished leaven. It is because of the fact that at the ratio of flour and hop broth 1:3 brews water is bound by starch at brewing flour, whereas at preparing leaven using denser brews, some amount of unbound water is additionally introduced in leavens.

It was established, that at using the four-phase method in leaven introduction in the amount $50,0 \%$ in ferment, the acidity of dough and bread was the same as at using the three-phase method of preparation (Fig. 1). At using leaven in the amount 25,0\% the acidity of dough and bread was by 2,0 degrees lower. The duration of keeping dough semi-products shortened at using ferments by $28 \mathrm{~min}$ and $14 \mathrm{~min}$, respectively.

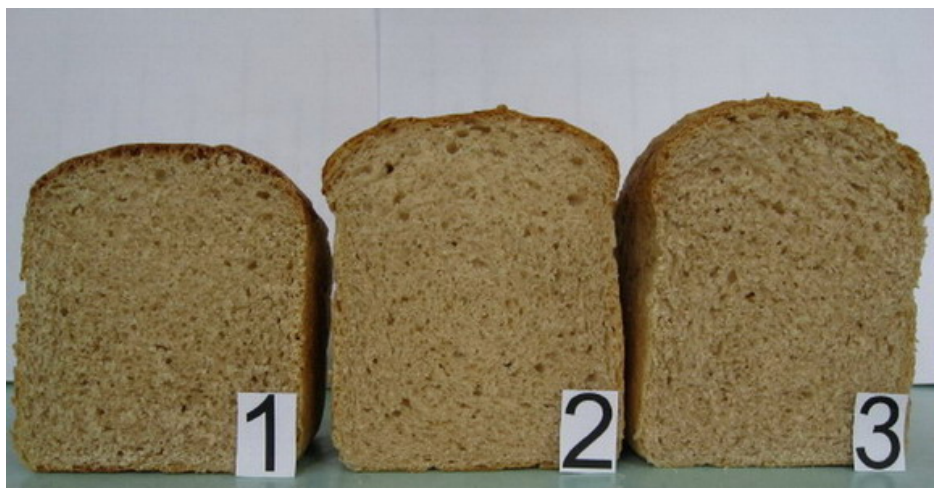

Fig. 1. Photos of samples of bread "On hop", prepared of dough": 1 - on hop leavens in the amount 50,0\%; 2 - on ferment using hop leavens in the amount 50,0\%;3 - on ferment using hop leaven in the amount $25,0 \%$

At introducing leaven in the amount 50,0\% and 25,0\%in leaven, the amount of fixed acids in dough decreases in 2 and 3,4 times respectively.

Bread on ferments had the more specific volume by $13,2 \%$ at using 50,0 \% of leavens and by $24,2 \%$ at using $25,0 \%$ of leavens. Bread on ferment had the attractive look, elastic crumb, even thin-walled porosity, more expressed smell. The last fact was confirmed by the more amount of bisulphaite-binding substances (11,5 - 12 $\mathrm{ml} \mathrm{0,1} \mathrm{n}$ iodine solution for $100 \mathrm{~g}$ of DS).

\section{Conclusions}

The obtained data testify that 1,5 times increase of the initial amount of sugars in these leavens favors the improvement of their lifting force and slightly influences the growth of acidity comparing with leavens that contain $6,0 \%$ of brewed flour. The increase of the moisture mass share in these leavens from $78,0 \%$ to $82,0 \%$ also slightly influences their acidity and lifting force.

It was established, that better conditions of hop leavens preparation are created at the moisture mass share in them $82,0 \%$, at introducing of $6,0 \%$ of flour with brew, and at introducing $12,0 \%$ of brewed flour, the moisture of leavens may be $78,0 \ldots 82,0 \%$. The temperature of hop leavens must be kept as $28 \ldots 29^{\circ} \mathrm{C}$.

The conducted studies of rheological characteristics of bitter brews demonstrated that the highest viscosity is inherent to bitter brew, prepared at the ratio of flour and hop broth 1:2. In the process of sugaring the viscosity of brews decreases, but the ratio of viscosities remains the same.

The comparison of rheological characteristics of hop leavens demonstrated that the use of more liquid brews (the ratio of flour and hop broth 1:3) for their preparation and increase of the amount of brewed flour, introduced in them, results in the growth of their viscosity. It is obviously 
explained by introducing the more amount of bound water with brews. In the process of fermentation the viscosity of leavens, that contain $12,0 \%$ of flour, increases.

At using the four-stage method of preparing dough by the scheme: bitter brew - hop leaven - ferment - dough, the quality of bread on hop leavens increases. The decrease of hop leaven dosage in ferment from $50,0 \%$ to $25,0 \%$ of flour mass in dough makes it possible to decrease the bread acidity by 2 degrees. It gives reasons to recommend it for preparing bread of wheat sorted flour.

\section{References}

[1] Paschenko, L. P., Zharkova, I. M. (2014). Tehnologiya hlebopekarnogo proizvodstva. Saint Pes tersburg: Lan, 672.

[2] Koryachkina, S. Ya., Sattsaeva, I. K. (2015). Pat. 2262233 RU. Sostav pitatelnoy sredyi dlya hmelevyih zakvasok. MPK A 21D 2/36. No. 2004104920/13; declareted: 17.02.2004; published: 20.10.2005, Bul. No. 29.

[3] Klinduhova, Yu. O. (2012). Sovershenstvovanie tehnologii hlebobulochnyih izdeliy s ispolzovaniem produktov pererabotki hmelya. Izvestiya vysshikh uchebnykh zavedeniy. Pishhevaya tekhnologiya, 3, 33.

[4] Malynovskyi, V. V., Belei, O. V., Bukshyna, L. S., Dakhno, B. M., Tserkovna, S. M. (2008). Pat. 81817 UA. MPK A 21 D 8/02 Sposib vyrobnytstva khliba na khmeliu. No. u 200512739; declareted: 28.12.2005; published: 11.02.2008, Bul. No. 7.

[5] Yurchak, V., Rak, V., Dakhno, B., Cerkovna, S. (2009). Povertayemosya do pryzabutoyi tekhnologii vypikannya khliba na khmelevykh zakvaskakh. Khlibopekarska i kondyterska promyslovist Ukrainy, 3 (52), 39-41.

[6] Drobot, V. I. (Ed.) (2015). Tekhnokhimichnyi kontrol syrovyny ta khlibobulochnykh i makaronnykh vyrobiv. Kyiv: Kondor-Vydavnytstvo, 972.

[7] Lebedenko, T. Ie., Pshenyshniuk, H. F., Sokolova, N. Iu. (2014). Tekhnolohiia khlibopekarskoho vyrobnytstva. Praktykum. Odessa: Osvita Ukrainy, 392.

[8] Vasyukova, A. T., Puchkova, V. F. (2010). Modern technologies of baking of bread. Moscow: Dashkov and To, 224.

[9] Tsyiganova, T. (2014). Tehnologiya i organizatsiya proizvodstva hlebobulochnyih izdeliy. Mosi cow: Akademiya, 448.

[10] Reuben, B., Coultate, T. (2009). Bread chemistry. On the rise. Chemistry World, 10, 54-57. 